\title{
HOLISTIC MARKETING IN THE FUNCTION OF COMPETITIVENESS OF THE APPLE PRODUCERS IN BOSNIA AND HERZEGOVINA
}

\author{
Dalibor Dončić ${ }^{1}$, Nenad Perić ${ }^{2}$ Radivoj Prodanović ${ }^{3}$
}

\begin{abstract}
The aim of the work is the analysis of current business situation in which the apple producers in Bosnia and Herzegovina are positioned with development and use of holistic marketing concept as a model for improving the competitiveness of apple producers in Bosnia and Herzegovina. The methodology, which is applied in this work, is a combined qualitative and quantitative research technique. The in-depth interview is used for qualitative research, and for quantitative research the analysis of the import, export, production, trade and the cash flow data, available from statistical agencies, were used. The results showed that the new, developing, apple production strategy is necessary in order to correspond to the business challenges of the $21^{\text {st }}$ century. In the new model of developing, it is suggested that the holistic approach to marketing has the central role. Holistic marketing, with its elements, has a potential to improve competitiveness on the domestic market and to create conditions for stable development of the apple production in Bosnia and Herzegovina.
\end{abstract}

Key words: holistic marketing, competitiveness, producers, apple.

JEL: $Q 13, M 31$

\section{Introduction}

After 1995, there was an increased interest of the producers for apple production, but in the past few years the business results have shown the trends of stagnation in apple production.

The poor business results have caused inability of the apple producers to renew the production cycles with their own finances, and because of the lack of the favorable and low-cost loans, they became indebted and further worsen the problem of solvency. The evident decline in income and revenue and also the income oscillations with constant increase of the costs

1 Dalibor Dončić, M.Sc., Ph.D. Student, Syngenta, Vidovdanska Street no. 18, 78400 Gradiška, BiH, Phone: +387 65814 709, E-mail: dalibor.doncic@syngenta.com

2 Nenad Perić, Ph.D., Associate Professor, Metropolitan University, Tadeuša Košćuška Street no. 63, 11000 Belgrade, Serbia, Phone: +381 112030 885, E-mail: nenad.peric@metropolitan.ac.rs

3 Radivoj Prodavnović, M.A., Faculty of Economics and Engineering Management, University Business Academy, Cvećarska Street no. 2, 21000 Novi Sad, Serbia, Phone: +381 658927 396, E-mail: rprodanovic@fimek.edu.rs

EP 2015 (62) 2 (309-323) 
in apple production, from year to year, caused abandonment of production and a constant decline of investments.

The problem of the research shows and defines the subject of the research, which are apple producers, with the economic effects they achieve in the production, the business orientation of the apple producers, as well as the apple market, as it is shown in the first part of the research in order to precisely define the problem. In the second part of the research, the development of the modernized production using holistic marketing as a response and a way for overcoming some existing problems in the production and apple trading are shown.

The purpose and goal of the research are the analysis and the evaluation of the current situation in apple production from the aspect of business concepts. It is believed that the results will provide undeniable arguments for implementing the model of holistic marketing in the apple production and trade.

The research combines different methods and techniques, such as the qualitative method with reference to in-depth interview, as well as the SWOT analysis regarding the quantitative research of the apple production in Bosnia and Herzegovina.

Results of conducted qualitative research technique of in-depth interviews with the apple producers and applied SWOT analysis compared with the quantitative analysis of the areas and production point to one seemingly paradoxical situation. Namely, the statistics show excellent indicators of production area growth, while the situation in the field implies economically difficult situation of all apple producers.

Based on this research, the conclusions were made indicating that the accumulated problems in the apple production and trade require a new model of development of apple production in Bosnia and Herzegovina. The conclusions indicate that a holistic marketing with its elements of internal, integrated, and socially responsible and relationship marketing can provide a good framework and direct the development of apple production towards success.

\section{Literature review}

At the beginning of the 21st century, the environment of business entities in the world was changing whit such a rate, intensity and unpredictability that it requires new approaches to business practice. The marketing concept, which had appeared and developed in the 50s of the past century, acted as if it had been looking for some natural upgrading or lifting onto new level of possibilities, as a response to the growing uncertainty in business. That new approach, which exceeds the traditional usage of the marketing concept, is named in a different ways and it is slowly getting attention of the leading professors, as a concept of holistic marketing. The concept of holistic marketing starts with the development, design and implementation of marketing programs, processes and activities, which recognizes the extent and interdependence effects (Kotler, 2006). Practice and science quickly perceived the extent and interdependence of the holistic marketing concept so that it is elaborated by both individual elements, such as the example in the holistic approach to internal marketing (Purcarea, Ratiu, 2011; Munteanu et al., 2014), as well as in the example of a whole theory 
about holistic marketing capabilities at company level (Patwardhan, 2014). For this research, the use of the holistic marketing in the education of farmers and small artisans in the large number of European countries is especially interesting. European education and training program organized the educations named „Holistic marketing for women farmers“ (Lifelong Learning program, 2008) and „Holistic marketing for micro companies in the trade sector" (Lifelong Learning program, 2012). The new legal framework emphasizes the clear direction of the robust growth and creating business in rural areas. All this was in accordance to Lisbon strategy and for improving sustainability in accordance with sustainable goals from Gothenburg (European Commission, 2005).

Development of business concept in the region is being followed from marketing to holistic marketing and also holistic brand management in various researches (Gligorijević, 2006; Stanković, 2007; Đukić, 2008). The possibilities of applying holistic marketing in a variety of profitable and non-profitable activities, and to applying holistic marketing in production and marketing of organic food and all in terms of sustainable development (Davčik, 2006; Rakić, Rakić, 2007; Panić, 2011; Grgar, Radinović, 2013). Previously, the importance of marketing of agricultural products in the process of developing the national economy and the agricultural sector was well-researched. The importance of marketing of agricultural products is great, thus we have the analysis of marketing in agriculture with special focus on the specifics of agricultural products which dictate special approach to marketing mix instruments (Paraušić et al., 2007; Vlahović, 2011). We especially emphasize the important research on marketing business orientation of the small and medium agro-industrial companies, and also the affirmation of associating and marketing in the function of creating competitiveness in the agrarian sector (Cvijanović, Milenković, 1995; Cvijanović, 2000; Cvijanović, Popović, 2002).

The business activities of the fruit producers in $\mathrm{BiH}$ are mostly analyzed from the aspect of quantitative indicator, based on the official statistic data from respected institutions like „Agency for Statistics of $\mathrm{BiH}^{\prime \prime}$ which includes import and export of goods according to customs procedures (Ćejvanović et al., 2014). The agricultural market and the basic conditions have also been under the research, including the structure of the crop production, vegetable production, fruit production and cattle production with the analysis of the market demand for agricultural products (Vukmirović, 2004). The unbalanced supply and demand, and also the variation of the fruit selling price, represents the important research for better understanding business problems of the fruit producers in BiH (Vaško et al., 2010). The literature review reveals the lack of qualitative and quantitative research about possibilities of the marketing usage in fruit production and trade in $\mathrm{BiH}$ and all that has been done for better understanding and improving regional competitiveness of the apple producers in $\mathrm{BiH}$.

\section{The research methodology}

The research methodology of the business and marketing orientation analysis concerning fruit producers is the combination of qualitative and quantitative research. Qualitative research precedes quantitative research in order to collect enough information about the elements and characteristics of the business and marketing orientation of the fruit producers. Further 
verification of this information on a representative sample implies continuing of research with quantitative methods. The structured questionnaire was used as an instrument of the research. In-depth interviews were organized in Lijevče polje and Potkozarje, as the most important regions for fruit production in Bosnia and Herzegovina (Dončić, 2014). Survey using indepth interviews included a total of ten respondents from the population of agricultural fruit producers. Participants were selected using intentional sampling method. Surveyed farmers were selected based on the size of land area that they cultivated (with 2 ha to 10 ha) as well as medium-scale producers in Bosnia and Herzegovina, which represent the most vital part of agricultural producers.

The secondary source of the information was Agency for Statistics of Bosnia and Herzegovina which provided data with the statistic annuals and Statistical Yearbook and Bulletins. FAO Statistic Data Base and publications were also used as source.

\section{The results and discussion}

The crisis in the production and trade of apples is particularly deepen by the general economic situation in the country, reducing foreign investment, high unemployment rate, reduced consumer purchasing power. All the above motivated the initiation of this study as an endeavor to explain the observed negative phenomena and weaknesses of the fruit producers with offering possible solutions in order to eliminate obstacles for further successful development of apple production in Bosnia and Herzegovina.

\section{The apple market in Bosnia and Herzegovina}

In the Table 1, following elements of the apple market in Bosnia and Herzegovina were analyzed: the number of trees, the estimated area covered with the apple trees, the area growth through the observed period, the apple production, etc.

Table 1. Number of trees, produced amounts and yields (period 2005-2013)

\begin{tabular}{|c|c|c|c|c|c|}
\hline Year & Number of trees & $\begin{array}{c}\text { Estimated } \\
\text { number of } \\
\text { hectares }\end{array}$ & $\begin{array}{c}\text { Index } \\
\mathbf{2 0 0 5}=\mathbf{1 0 0} \%\end{array}$ & Production (t) & $\begin{array}{c}\text { Yields per } \\
\text { tree (kg) }\end{array}$ \\
\hline 2005 & $3,426,944$ & 1,505 & 100 & 52,181 & 15.2 \\
\hline 2006 & $3,711,468$ & 1,630 & 108 & 58,109 & 15.7 \\
\hline 2007 & $3,982,891$ & 1,750 & 116 & 60,962 & 15.3 \\
\hline 2008 & $4,189,878$ & 1,840 & 122 & 51,946 & 12.4 \\
\hline 2009 & $4,610,256$ & 2,025 & 134 & 71,507 & 15.5 \\
\hline 2010 & $4,812,681$ & 2,114 & 140 & 71,660 & 14.9 \\
\hline 2011 & $5,284,959$ & 2,322 & 154 & 75,334 & 14.3 \\
\hline 2012 & $5,610,522$ & 2,465 & 163 & 50,023 & 8.9 \\
\hline 2013 & $6,223,340$ & 2,734 & 181 & 85,117 & 15.7 \\
\hline
\end{tabular}

Source: Authors' calculation according to data from ASBH, 2014. 
Areas. In statistics of Bosnia and Herzegovina, the areas covered with the apple trees were not evident from the official statistics because the data were provided by the old methods based on the number of fertile trees. The areas can only be estimated based on the number of trees, which have been planted in recent years, concerning the unit area. Based on in-depth interviews with experts in the field of fruit production it is estimated that in the recent decades the rootstock M106, which is planted at a spacing of $4 \mathrm{~m} \times 1.5 \mathrm{~m}$, in a row and rootstock M9, planted at a distance of $1 \mathrm{~m}$ in a row and $3.5 \mathrm{~m}$ between the lines, are equally present. If the average value of the planting density is calculated, the 2,276 trees/ha were planted in average, which makes an estimation of 2,734 ha with fruit trees in 2013. It is immediately noticeable that the trend is opposite comparing to the world trend where the areas under apple orchards are decreasing, while in Bosnia and Herzegovina areas under apple plantations are increasing rapidly, thus the surface area increased by over $80 \%$ compared to the reference year of 2005 (Table 1.).

Production. The apple production in Bosnia and Herzegovina follows the growth of the areas. The production increased from 50,000.00 tons in 2005 to $85,000.00$ tons in 2013, which represents the significant growth. This trend of significant growth deviated only in 2012 and it was caused by the frost at the time if apple flowering. In the segment of the production growth, the trends in Bosnia and Herzegovina are equal with the world trends, including the growth of the overall production (ASBH, 2014).

Yields. Yields per tree are about $14 \mathrm{~kg}$ (ASBH, 2014) and if the estimated numbers of 2,276 trees per hectare are analyzed, the average yield is $34 \mathrm{t} / \mathrm{ha}$, which is a fairly good indicator. However, it also represents the need for improvement, if compared with Austria and Italy, where the average yield exceeds $60 \mathrm{t} / \mathrm{ha}$. Apple fruit production in Bosnia and Herzegovina varies due to the weather conditions and it suggests possible use of modern technology for reducing these oscillations. The average yields achieved in Bosnia and Herzegovina can be considered as satisfying, and the problem is in the structure of classes which is highly unfavorable. Participation of the extra and the first class is minor and it fluctuates significantly, therefore it represents one of the main reasons for the poor profitability for the apple producers in Bosnia and Herzegovina.

Trade. The total apple trade in Bosnia and Herzegovina is around 87,000 tons. Domestic production covers 64,000 tons, the average import of the apple covers 23,000 tons and the export covers about 5,000 tons in the studied period (ASBH, 2014). The distribution chains in Bosnia and Herzegovina are long and between producers and consumers there is a repurchase process in the wholesale and retail. A large number of apple retailers and a small number of customers cause low purchase prices for producers and high selling prices in retail stores. All the difference in the prices is claimed by purchasers and retailers especially supermarkets.

The purchase price of apples during harvest time, when $90 \%$ of the producers sell the apple because they do not have the possibility for storage, was $0.40 \mathrm{KM}$ for many years and the price went up to $0.47 \mathrm{KM}$ in 2010 . However, in 2011 there was a decrease in price by nearly $20 \%$ comparing to the previous year. In 2012, there was a strong frost at the time 
of apple flowering in Potkozarje area, and the fruit producers lost about $90 \%$ of yield, according to the official statistics of the State Commission for Damage Assessment. The fruit producers made no profit from price increase caused by the small supply of domestic apple. Especially worrying were 2013 and 2014 when the purchase prices were $0.35 \mathrm{KM}$, which is the lowest price in the studied period and 10\% lower from the average purchase price in the last decades (Table 2).

The lower prices, with the frost in 2012, make the last three years extremely unfavorable for the apple producers and they were cause for many problems in financing further production (Table 2). These low purchase prices of apples are extremely unfavorable if we compare them with the prices of raw material, which has the permanent and constant growth from minimum $3 \%$ per year, as it was established by the analysis and field research.

Table 2. The average purchase apple prices from 2006 to 2014

\begin{tabular}{|c|c|c|c|c|c|c|c|c|c|}
\hline Year & $\mathbf{2 0 0 6}$ & $\mathbf{2 0 0 7}$ & $\mathbf{2 0 0 8}$ & $\mathbf{2 0 0 9}$ & $\mathbf{2 0 1 0}$ & $\mathbf{2 0 1 1}$ & $\mathbf{2 0 1 2}$ & $\mathbf{2 0 1 3}$ & $\mathbf{2 0 1 4}$ \\
\hline Price KM & 0,41 & 0,40 & 0,41 & 0,45 & 0,47 & 0,39 & 0,57 & 0,35 & 0,35 \\
\hline
\end{tabular}

Source: According to Dončić, 2014.

Consumption. The fresh apple consumption per capita in Bosnia and Herzegovina is estimated to $12 \mathrm{~kg}$ per year (ASBH, 2014). The apple consumption per capita annually is higher than the average consumption in the world, which is $8.4 \mathrm{~kg}$, but it is behind developed countries of EU, where the consumption of the fresh apple per capita is $50 \mathrm{~kg}$ per year (FAO, 2014). The specific problem in Bosnia and Herzegovina regarding the increased apple production is different from the apple production in the world, where the increase of the production was followed by the increase of the apple consumption. The apple consumption in Bosnia and Herzegovina has been stagnating for years, and the increased production and supply in these conditions, as well as the demand, caused price drop which is negatively reflected on the profitability and sustainability of the apple producers in Bosnia and Herzegovina.

Trends. The trends in the production and the offer of the fresh apple demand the constant innovations from the production technology itself. Health, environment protection, high ecological standards of the raw material, reduced usage of agrochemicals and new systems of production, for example integral production, organic production and constant certification are required. These innovations are especially seen in assortment and in the constant improving of colors, appearance and organoleptic characteristics of the apple. There is also a trend of creating club-apple varieties with a lot of limitations in their reproduction. Special innovations are in apple packing, small packages containing 2 to 6 apples of different varieties in one package and the packages are made from ecological material. Labeling and traceability of the product origin back to the orchard in which the apple was produced are also important. The apple producers in Bosnia and Herzegovina rarely make the effort to follow these innovations and the reasons for that are mainly lack of knowledge, fragmentations, financial weakness and the low level of the organization. 


\section{SWOT analysis of the apple industry in Bosnia and Herzegovina}

In the analysis of the condition of the apple industry in Bosnia and Herzegovina, the central place takes SWOT analysis, made in the cooperation with the experts from the area of apple production. SWOT analysis perceived inner or the internal weaknesses and strength as well as the external or outward threats and opportunities, and all in order to be able to identify main problems and develop models for elimination of restrictions and for opening possibilities for the further successful apple production.

The internal analysis of weaknesses and strength

Table 3. The internal analysis of the weaknesses and strength of the apple producers

\begin{tabular}{|c|c|}
\hline Weaknesses & Strengths \\
\hline Seedlings & \\
Land preparation & \\
Assortment & Climate \\
Mechanization & Land \\
Netting & Water \\
Irrigation & Fruit growers \\
Cooperatives & Agronomists \\
Financial strength & Institutions \\
Supply of high percentage of II class & \\
Purchase of raw material & \\
Negotiating positions & \\
Modern warehouses & \\
Customers & \\
\hline
\end{tabular}

Source: According to Dončić, 2014.

Weaknesses. Seedlings, regardless of the clear legislation on quality norms, are of poor quality. Poor quality of seedlings have been is especially present since 1995, after the war, when the seedling demand increased and the seedling material was imported from the nearby countries, without any control and monitoring. This poor quality is especially reflected in the authenticity of varieties where the real condition deviates from the declared condition, as well as in the regression of the varietal characteristics where the varieties have worsen their typical characteristics such as the color, shape, taste, etc. (Table 3).

The land with its physical, chemical and biological features was not properly considered when it comes to raising apple orchards. In order to have fewer expenses, the growers' neglected problems such as acid land, pseudogley soil, the lack of the organic substances, and so on, which had the catastrophic consequences on numerous orchards and also caused bankruptcy of some fruit growers.

The technology of the apple production with the good selection of adequate rootstock and the production system, often worked by the inertia and new trends in demanding extra and first class apple were not considered. Financial insolvency also caused small percentage of orchards with integrated anti hail screens or irrigation systems. 
Cooperative associations practically did not exist and the problem of the fragmentation of parcels is pronounced because most of the small-scale growers had weak negotiation positions with raw material suppliers and also with the consumers of their products, which are in considerably small number and they have strong negotiation positions.

The product quality, caused by many errors, is poor. The main errors, which affect the product quality, are poor seedlings quality, unprofessional soil preparation and low technological level. According to the assessment by the experts, the average quality classes of apples were $50 \% \mathrm{I}$ class, $25 \%$ II class and $25 \%$ III class. To be profitable and self-sustainable, the experts believe that the apple growers should reach the level of $80 \%$ I class, $15 \%$ II class and $5 \%$ III class which is hard to achieve without serious reconstruction and the new model for improving the apple production, according to the research in the field.

Strengths. The climate elements are important for apple production and for the quality of fruits, such as sun light, heat, temperature, water and humidity with precipitations, as well as with the clean rivers, rain, snow, hail, frost and wind which are good for the apple production and high quality of fruits, in the observed area (Table 3 ).

Soil is reflected through the strength of apple production because it possesses the fertility potential and supplying plant with air, water and mineral substances, but only with appropriate preparation, because of its specificity which must not be neglected during raising plantations.

Human resources are also the strength of apple production because we have young fruit growers who make new plantations and want to stay in the courtsides and work on fruit production. The manpower in regards to EU is much cheaper. Therefore, the apple production should be competitive advantage for the domestic apple producers. Agronomists are also one of the strengths of the apple production. The number and the education of agronomists are the subjects for discussion and debate in the professional community, but they also represent good foundation for further growth. Institutions, such as Agricultural Faculty, Agricultural Institute, Ministry of Agriculture with their experts, also represent strength and a good foundation for forming a strong and precise strategy of progress, as well as its implementation.

\section{External analysis of threats and opportunities}

Table 4. External analysis of threats and opportunities for apple producers

\begin{tabular}{|c|c|}
\hline Threats & Opportunities \\
\hline Weather extremes & Domestic market \\
New pests & Foreign markets \\
New causal agents & New fruit species \\
Agrochemicals & New varieties \\
Foreign competition & Indigenous varieties \\
Supermarkets & Integrated production \\
Purchasing power of customers & Processing \\
Fruit consumption & Organic production \\
Processing & Certification \\
Loans & \\
\hline
\end{tabular}

Source: According to Dončić, 2014. 
Treats. The weather extremes, which have specific negative impact and appear very often, are hail, frost, drought and floods. Technologies, for example, anti-hail screens, anti-frost systems, irrigation, canals and drainage were not widely used in the apple production due to expensive implementation (Table 4).

New pests and new causal agents present a complex problem and the cooperation of the various science and professional institutions is needed in order to develop a model for monitoring these natural factors.

The uncontrolled use of agrochemicals, without enough knowledge and awareness about the harmful consequences, is also a major threat to contamination of the product and further deterioration of the image of domestic apple growers. Controlled and proper use of agrochemicals and a good communication with customers is the basis for building trust and gaining competitive advantage in the domestic market.

Competition is present with an average of 23.000 tons and holds $20 \%$ to $25 \%$ of the domestic market (ASBH, 2014). The main competitors are Macedonia, Poland and others, where Macedonia and Poland compete in the segment of low apple prices. Italy and Austria are competing in the segment of high apple prices, thus the domestic producers are disadvantaged and hardly can secure their market. Free trade agreements, such as CEFTA, further liberalize market he market and complicate the development opportunities in the domestic market. Foreign-owned supermarkets have been a strong competition for local traditional farmers markets are favorable to foreign supplier while putting domestic apple producers in subordinate position.

Purchasing power of consumers in Bosnia and Herzegovina, with the economic crisis, has a significant impact on the apple consumption and it is considered to be on the level of $12 \mathrm{~kg}$ per capita, per year with declining trend (ASBH, 2014). Decline in apple demand, together with the growth of production, inevitably leads to prices decline and to the problems of sustainability for fruit growers. Apple consumption, without the stimulation and promotion programs, will certainly continue to decline, and therefore the support is needed for the apple producers and for consumers to raise awareness about the consumption of the apple for health purposes. The apple producers have to rely on the support the government institutions and agencies.

Opportunities. The domestic market represents the greatest opportunity for the apple producers because there is high import percentage and low consumption. These are the two segments which must be seen as a development option, i.e. program to replace import with domestic production and promote small-scale apple consumption per capita, per year. Strengthening position in domestic market should follow systemic approach to foreign markets where the most perspective are considered to be the Russian Federation market and Arabian market (Table 4).

The new fruit species, as well as the new varieties, especially indigenous and original, should be one of the systemic program measures for finding new products in offer differentiation and the attempt of creating the extra value. The apple producers are unable to seek for new fruit 
species and varieties themselves, and once again referred to cooperate with both foreign and domestic institutions.

The new systems of the agricultural production, which include organic food, functional food, integrated fruit production and ecological production, can also be the source of the competitive advantage. These productions must be followed by quality certification with standards and also with the communication with consumers.

Processing and new products such as juices, cider, beer, as well as some traditional products such as compotes, sweets, jams, are the possibilities which have not been paid enough intention to, so they remained insufficiently used as a method of creating the new value in the apple and fruit production in general.

\section{The concept of holistic marketing in the apple production}

It is assumed in the holistic approach that everything is significant in business and that in practice a comprehensive and integrated cooperation is often required. All economic entities apple producers need a new approach to work and competition with regard to the new marketing environment.

The components of the holistic marketing are (Kotler, 2006):

$\varnothing$ Internal marketing - commitment of everyone in the organization to use the appropriate marketing principles;

$\varnothing$ Integrated marketing - commitment to use multiple instruments of creating, delivery and communication of values and their optimal combination;

$\varnothing$ Socially responsible marketing - understanding the ethical, legal and social influence of the organization, as well as the organizational influence on the environment; and

$\varnothing$ Relationship marketing - creating the exceptional, multilateral relations with customers, suppliers and other partners.

Internal marketing in the apple production. The internal marketing, as a component of the holistic marketing, ensures that everyone in the organization of the fruit growers or apple producers accepts appropriate marketing principles. Accepting marketing principles, using internal marketing, is particularly important for the holders of households at the level of fruit families, but also for the organizers of production, management associations and cooperatives. The internal marketing has a task to train and motivate the apple producers in order to serve to the customers in the best way. Holistic marketing understands that the business activities, inside the production unit, can be equally important as well as the activities which are directed outside these forms of organization. The internal marketing is performed on several levels and several business functions, but the common thing is that marketing functions have to be coordinated towards customer point of view.

The main role of the internal marketing in the holistic approach to marketing in the apple production is in the power of internal marketing to reach out to every manufacturer and to 
convince them that they have the influence on the consumer with all their activities, raw material purchase, proper use of agrochemicals and the other important activities. Therefore, if the above mentioned activities are used properly and if the communication with the consumers is well, this all can be a competitive advantage, but also it can be a high risk for the quality placement of fruit if errors are made.

Integrated marketing in the apple production. The task of the integrated marketing is to design the marketing activities and include them into integrated marketing programs in order to create, communicate and deliver the values for consumers above the expected or common. The integrated marketing program consists of a series of decisions related to improvement of business process aspects. The integration of activities and marketing process aims to maximizing their common effects.

In other words, planning and implementation of any marketing activities have are carried out taking into consideration all the other activities. Improvement of business processes cannot be achieved with buying cheaper raw material without its origin, because it is contrary to and in conflict with health safety standards of products. The integrated marketing allows the coordination of the purchase, health product safety standard and communication about these values with customers.

Relationship marketing in the apple production. The main goal of marketing became the development of close, long-term relations with all individuals and organizations that can directly or indirectly influence on the success of the apple producers' marketing activities. Relationship marketing aims to build mutually satisfying relationships for the most important parties. The key parties in the business relations are consumers, buyers, suppliers, distributors and the other partners in marketing, in order to obtain and maintain jobs.

For agricultural producers, including the apple growers, the key parties also include the Ministry of Agriculture, Forestry and Water Management, Agricultural Institutes, Agricultural Faculties, state and republic agencies, all in the position for providing services in agriculture and all the other institutions, which are directly or indirectly involved in issues related to food, agriculture or the environment. The influence of these institutions on the development, and the competitive advantage of fruits and vegetables producers, can be enormous.

The final result of the relationship marketing is building the unique marketing property which is called marketing network. Marketing network, in the case of fruits and vegetables producers, consists of producers and their supporting stakeholders (consumers, customers, suppliers, distributors, retailers, agencies, scientists, professional workers, state institutions, etc.).

The concept of socially responsible marketing in the apple production. Socially responsible marketing is included into the holistic approach to marketing and it involves understanding of the wider interests and ethical contexts, and also the context of the environment, legal and social marketing activity and the program. The main goal of the company and of the individual is a successful business that makes profit. Every business takes place in the 
community that has its expectation and rules, and also in a limited environment such as in a market, which is strongly influenced by the community. Taking this into consideration, development of the modern concept of socially responsible marketing is becoming an important factor of competitiveness.

The apple producers represent the part of the agricultural food production that is subjected to many issues today, such as environmental protection, ethical use of new technologies, safety and food safety. These are the reasons why it is socially responsible marketing, for the apple producers, essential in their communication with consumers. Risk management in food production has significantly been developed in the last decades.

\section{Conclusions and recommendations for further research}

In the analysis of the apple industry in Bosnia and Herzegovina, besides good statistic indicators that relate to the growth of the areas covered with apple orchards, SWOT analysis has shown many weaknesses and threats that are present in this once highly profitable production of fruits. It has also shown the insufficient use of strengths and opportunities, which in overall indicates the great reduction of the domestic apple producers' competitiveness.

The areas covered with apple in Bosnia and Herzegovina are estimated on more than 2,700 hectares and they have increased by over $80 \%$ since 2006 . However, the rapid growth of areas and production was accompanied by many system failures that have led to a very difficult financial position of the fruit producers in Bosnia and Herzegovina. The economic crisis and the decline in the apple consumption, with the strong competitors on the domestic market, caused the decline in selling prices and the problem of sustainability of the apple producers.

SWOT analysis revealed many weaknesses of which we particularly point out the poor quality of planting material, unprofessional land preparation, outdated technology, lack of cooperatives, poor quality of final products, fragmented supply of raw material and the low offer. Weather extremes, new pests, disease causal agents, unprofessional use of agrochemicals, a strong presence of foreign competition which holds approximately to $25 \%$ of the market in Bosnia and Herzegovina, supermarkets which are taking over the apple trade and for those actions the domestic producers are not ready, are most important threats.

In the future development of the apple industry, a new systematical, organizational and managing model must be developed, in order to minimize and reduce these weaknesses and threats, and to maximize the strengths as climate, lands, people and opportunities, as well as domestic market, new varieties and new systems of production. This new model represents the implementation of holistic marketing which with its elements, internal marketing, integrated marketing, socially responsible marketing and relationship marketing, corresponds to the challenges which are brought to the apple producers in $21^{\text {st }}$ century.

Research results of the apple producers in Bosnia and Herzegovina can be used in a function for strengthening regional competitiveness of the mentioned producers through identifying 
the weaknesses and suggesting on activities for overcoming the obstacles. The fruit producers need the assistance from the government institutions to be able to adopt marketing orientation and holistic marketing in order to improve competitiveness.

\section{Literature}

1. Agency for Statistics of B\&H (ASBH), Statistical yearbooks for the period 2006 to 2014, database of ASBH, Sarajevo, available at: http://www.bhas.ba/index. php?option $=$ com publikacija \&view=publikacija pregled\&ids $=4 \& i d=14 \& n=$ Poljoprivre da, accessed at: February, 2015.

2. Cvijanović D., Milenković, S. (1995): Marketing poslovna orijentacija agroindustrijskog preduzeća - Institut za kukuruz "Zemun Polje” Beograd, Zbornik radova, Simpozijum Inovacije u agrobiznis menadžmentu, Aranđelovac, pp. 3-5.

3. Cvijanović, D. (2000): Uticaj istraživanja marketinga na donošenje odluka i njihova povezanost u poljoprivrednom preduzeću, Proceedings, Naučni skup sa međunarodnim učešćem, Razvoj sela i agrobiznisa - šta posle sankcija?, jun 2000, Kopaonik, pp. 299-307.

4. Cvijanović, D., Popović, V. (2002): Marketinška orijentacija preduzeća uslov razvoja malih i srednjih preduzeća u agrobiznisu Srbije, Ekonomika Poljoprivrede, vol. 49, no. 3-4, pp. 129-135.

5. Ćejvanović, F., Ivanković, M., Lasić, M., Vaško, Ž. (2014): The Impact of Foreign Trade in Agricultural products of Bosnia and Hercegovina within the Framework of CEFTA 2006, Economics of Agriculture, vol. 61, no. 4, pp. 975-987.

6. Davčik, N. (2006): Integralni ili integrisani marketing, Marketing, vol. 37, no. 3, pp. 133-138.

7. Dončić, D. (2014): Analiza poslovnog koncepta proizvođača voća, unpublished internal documentation (in-depth-interviews with selected fruit producers), Lijevče polje and Pokozarje, $\mathrm{BiH}$.

8. Đukić, S. (2008): Holističko upravljanje markom zasnovano na povjerenju i emocionalnoj privrženosti potrošača, tematski zbornik, Razvijanje konkurentske prednosti preduzeća u Srbiji u uslovima evropskih integracija, Univerzitet u Nišu, Ekonomski fakultet, pp. 123-134.

9. European Commission (2005): Putting rural development to work for jobs and growth, Directorate-General for Agriculture and Rural Development, available at: http://ec.europa. eu/agriculture/publi/newsletter/lisabon/special en.pdf, accessed at: February, 2015.

10.FAO (2014): Annual report, FAO STAT, available at: www. faostat.fao.org, accessed at: February, 2015.

11. Grgar, D., Radinović, B. (2013): Implementacija koncepta holističkog marketinga kao osnova uspešnosti reformi javnog sektora Republike Srbije, Poslovna Ekonomija, no. 1, pp. 177-194.

12. Gligorijević, M. (2006): Od marketinga do holističkog marketinga, Ekonomske teme, no. $1-2$, pp. 233-239.

EP 2015 (62) 2 (309-323) 
13. Kotler, Ph. (2006): Marketing menadžment, Beograd: Data status.

14. Lifelong Learning program (2008): Holistic Marketing for Women Farmers, Project type: Development of Innovation, contact person: Malschinger, A., available at: www.adameurope.eu/prj/4706/project 4706 en.pdf, accessed at: February, 2015.

15. Lifelong Learning program (2012): Holistic Marketing for Micro-enterprises in the Handicraft Sector, Center of the Republic of Slovenia for Mobility and European Educational and Training Programs, Slovenia, Ljubljana, Project no. LLP-LDV-TOI-03/12, available at: http://ec.europa.eu/education/tools/llp_en.htm, accessed at: February, 2015.

16. Panić, S. (2011): Holistički marketing u funkciji tržišne transformacije preduzeća iz sektora namenske proizvodnje, Vojno delo, vol. 63, no. 3, pp. 332-341.

17. Patwardhan, M., A. (2014): A partial theory of holistic firm-level marketing capability: An empirical investigation, Journal of Management and Marketing Research, vol. 16, pp. 1-46, available at: http://www.aabri.com/manuscripts/141880.pdf

18. Paraušić, V., Cvijanović, D., Subić, J. (2007): Afirmacija udruživanja i marketinga u funkciji kreiranja konkurentnosti agrarnog sektora Srbije, Institut za ekonomiku poljoprivrede, Beograd.

19.Purcarea, V., T., Ratiu, P., M. (2011): How to keep loyal relationships with service customers using holistic marketing, Holistic Marketing Management, vol. 1, no. 1, pp. 27-32, available at: http://holisticmarketingmanagement.ro/RePEc/hmm/v1i1/1/7.pdf

20. Rakić, B., Rakić, M. (2007): Holistički marketing organske hrane u funkciji održivog razvoja poljoprivrede, Zbornik radova, XV Naučno-stručni skup sa međunarodnim učešćem o prirodnim vrednostima i zaštiti životne sredine - EkoIst' 07 - Ekološka Istina, Sokobanja, pp. 218-222.

21. Stanković, Lj. (2007): Holistička organizacija marketinga, Ekonomske teme, no. 3, pp. 39-52.

22. Munteanu, C., Pagalea, A., Cristea, A. (2014): A Holistic approach on internal marketing implementation, Business Management Dynamics, vol. 3, no. 11, pp. 9-17.

23. Vaško, Ž., Ostojić, A., Drinić, Lj., Figurek, A. (2010): Utvrđivanje optimalnog momenta prodaje jabuka sa stanovišta uticaja troškova skladištenja, Agroznanje, vol. 11, no. 3, pp. 157-164.

24. Vlahović, B. (2011): Tržište i marketing poljoprivredno-prehrambenih proizvoda, Poljoprivredni fakultet, Novi Sad.

25. Vukmirović, N. (2004): Agricultural market in Bosnia and Herzegovina, Project: "Inventory of Post-War Situation of Land Resources in Bosnia and Herzegovina", GCP/BOSNIA AND HERZEGOVINA /002/ITA, available at: www.agrowebcee. net/...ba/.../Agricultural_market in_Bosnia and Herzegovina 1.pdf, accessed at: February, 2015. 


\title{
HOLISTIČKI MARKETING U FUNKCIJI KONKURENTNOSTI PROIZVOĐAČA JABUKE U BOSNI I HERCEGOVINI
}

\author{
Dalibor Dončićc ${ }^{4}$ Nenad Perićs, Radivoj Prodanović ${ }^{6}$
}

\begin{abstract}
Sažetak
Cilja rada je analiza aktuelneposlovnesituacije u kojem se nalaze proizvođači jabuke u Bosnia and Herzegovina sa razvojem i primjenom koncepta holističkog marketinga kao modela unaprijeđenja konkurentnosti proizvođača jabuka u Bosnia and Herzegovina. Metodologija primjenjena u radu je kombinovana kvalitativna $i$ kvantitativna tehnika istraživanja. Od kvalitativnih istražuivanja koristi se dubinski interviju a od kvantitativnih istraživanja analiza uvoza, izvoza, proizvodnje i prometa iz dostupnih statističih zavoda. Rezultati ukazuju da je potrebna nova strategija razvoja proizvodnje jabuke u Bosnia and Herzegovina da bi se odgovorilo na izazove koje nameće poslovanje 21. vijeka. U novom modelu razvoja predlaže se da holistički pristup marketingu ima centralnu ulogu. Holistički marketng sa svojim elementima ima potencijal da unaprjedi konkurentnost na domaćem tržištu i da stvori pretpostavke stabilnog razvoja proizvodnje jabuke u Bosnia and Herzegovina.
\end{abstract}

Ključne riječi: holistički marketing, konkurentnost, proizvođači, jabuka.

4 Mr Dalibor Dončić, doktorant na Univerzitetu Metropolitan, Syngenta, Vidovdanska 18, 78400 Gradiška, BiH, Telefon: +387 65814 709, E-mail: dalibor.doncic@syngenta.com

5 Prof. dr Nenad Perić, vanredni profesor, Univerzitet Metropolitan, Tadeuša Košćuška 63, 11000 Beograd, Srbija, Telefon: +381 112030 885, E-mail: nenad.peric@metropolitan.ac.rs

6 Radivoj Prodanović, M.A., Fakultet poslovne ekonomije i inženjerskog menadžmenta, Univerzitet poslovne akademije, Cvećarska 2, 21000 Novi Sad, Srbija, Telefon: +381 658927 396, E-mail: rprodanovic@fimek.edu.rs

EP 2015 (62) 2 (309-323) 